\title{
Servitization as a competitive difference in humanitarian logistics
}

\author{
Graham Heaslip* \\ School of Business, Galway Mayo Institute of Technology, Ireland \\ and \\ Humanitarian Logistics and Supply Chain Research Institute (HUMLOG Institute) \\ Hanken School of Economics, PO Box 479, 00101 Helsinki, Finland \\ graham.heaslip@gmit.ie \\ Tel: 00353(0)91742595 \\ Gyöngyi Kovács \\ Humanitarian Logistics and Supply Chain Research Institute (HUMLOG Institute) \\ Hanken School of Economics, PO Box 479, 00101 Helsinki, Finland \\ kovacs@hanken.fi \\ David B. Grant \\ Hanken School of Economics, PO Box 479, 00101 Helsinki, Finland \\ Hull University Business School, Hull, United Kingdom, HU5 1DA \\ david.grant@hanken.fi; d.grant@hull.ac.uk
}

*Corresponding author

The published version of this article can be found at https://doi.org/10.1108/

JHLSCM-08-2017-0042 
Revision for manuscript JHLSCM-08-2017-0042

\title{
SERVITIZATION AS A COMPETITIVE DIFFERENCE IN HUMANITARIAN
}

\section{LOGISTICS}

\begin{abstract}
:
Purpose This paper presents a literature review and conceptual consideration of servitization in humanitarian logistics. Its purpose is to provide a research agenda for humanitarian logistics scholars and insight for practitioners and by doing so will fill a gap in existing research and practice.

Design/methodology/approach The paper uses a literature-based approach that extends concepts usually applied in a commercial context to the area of humanitarian logistics.

Findings The paper initiates a discourse on the importance of taking into account servitization in developing and managing effective emergency relief chains. This paper argues that a broader servitization paradigm needs to be integrated for international humanitarian organisations to maintain a competitive advantage.
\end{abstract}

Originality/value We investigate servitization as a management innovation in international humanitarian organisations and plot a research agenda for scholars.

Keywords Servitization, service, humanitarian logistics, research agenda 


\section{SERVITIZATION AS A COMPETITIVE DIFFERENCE IN HUMANITARIAN LOGISTICS}

\section{Introduction}

In a continuous search for new ways of creating and enhancing value many organisations are looking for diversification opportunities in service markets related to their products (Abidi et al., 2015; Visnjic Kastalli and Van Looy, 2013). Although companies offer services to the market, the last few decades have seen the integration of products and services as a possibility for growth and competitiveness (Charles and Lauras, 2011; Jacob and Ulaga, 2008). The provision of services has now turned into a conscious and explicit strategy with services becoming a main competitive differentiating factor in a totally integrated products and service offering (Prockl et al., 2012; Baines et al., 2009).

This phenomenon, known as servitization, involves firms developing the capabilities they need to provide services and solutions that supplement their traditional product offerings (Vandermerwe and Rada, 1988), with the result that boundaries between products and services have become blurred as manufacturers have moved into providing added value services to their product offerings (Grönroos, 2011). Gummesson (1995) notes that all types of resources providing value for customers as services are used by them; not only service activities but also goods as distribution mechanisms for services (Dufour et al., 2018; Vega and Roussat, 2015; Vargo and Lusch, 2004). Thus, servitization is the innovation of a firm's capabilities and processes to shift from selling products to providing value-added services (Nätti et al., 2014; Baines et al., 2009). By adding services to core products, firms differentiate their offering from competitors, increasing customer dependency and establishing barriers to competition (Cozzolino et al., 2017; Barnett et al., 2013). 
Earlier studies of servitization focused on large manufacturing firms but increasingly interest is directed at organisations involved in delivering humanitarian aid (Bealt et al., 2016; Vega and Roussat, 2015; Kovács, 2014; Heaslip, 2013). Recent research involving aid organizations has directed much interest to humanitarian logistics due to $80 \%$ of humanitarian aid costs tied to logistical activities (Jahre et al., 2015; van Wassenhove, 2006). Humanitarian logistics (HL) is commonly defined as "the process of planning, implementing and controlling the efficient, cost-effective flow and storage of goods and materials, as well as related information, from point of origin to point of consumption for the purpose of meeting the end beneficiary's requirements" (Thomas and Mizushima, 2005: 60). An interesting trend in this context is that international humanitarian organisations (IHOs) have started to develop services that they offer to each other (Heaslip, 2013; Kovács and Spens, 2011), yet research on this topic is virtually non-existent (Vega and Roussat, 2015; Heaslip, 2013).

Further, most of the services IHOs offer to each other fall under the realm of logistics. For example, the World Food Programme (WFP) offers customs clearance, transportation and warehousing services through the Logistics Cluster to other organisations (WFP, 2013a; Jensen, 2012). They currently run the "common humanitarian transport" of Syria, and use over 4,600 trucks to deliver emergency food distribution to 900 distribution points. Working with over 50 local and international partners, WFP distributes food to between 4 and 5 million people every month in Syria (WFP, 2018). All these services are becoming rather standardised, with service request forms having been developed for each ongoing operation.

Also outside of the humanitarian context, Bask et al. (2010) and Saglietto, (2013) demonstrate the many good reasons to focus on research regarding logistics services. First, 
the outsourcing of logistics services is expected to increase; second, the logistics service industry is an emerging industry which promises a positive future and new roles in supply chains and value networks for the logistics industry. Thirdly, value added logistics services seem to be the fastest growing part of the transport industry. Moreover, as highlighted by Skjoett-Larsen et al., (2007) e-commerce has created major changes in the structures and processes of distribution. To summarise, in the future, logistics service providers are likely to continue to strengthen their value creation in supply chain networks both at global and local levels. At the same time, recent literature reviews in operations and supply chain management analysing contemporary themes, trends and potential future directions identify the continuing growth in service operations management and servitization as a potentially ripe area for further research (Chiappetta et al., 2017; Heaslip, 2015; Vega and Roussat, 2015; Leiras et al., 2014; Sheppard et al, 2013; Natarajarathinam et al., 2009; Taylor and Taylor, 2009; Craighead et al., 2007; Machua et al., 2007; Altay and Green, 2006; Gupta et al., 2006).

Research focusing on services and the processes of service provision in the context of humanitarian logistics is limited (Vega and Roussat 2015; Heaslip 2015). Much of the research in humanitarian logistics takes a narrow view focusing on goods, product, freight or distribution (Pedraza Martinez and Van Wassenhove, 2013; Pedraza Martinez et al., 2011). Recently a different perspective has been advanced, broadening the "narrow view" and emphasising the "service view" within humanitarian logistics (Bealt et al., 2016; Abidi, et al., 2015; Heaslip, 2015; Vega and Roussat 2015).

The perspective of HL as a service is growing within management studies (Dufour et al., 2018; Heaslip et al., 2108; Baharmand et al., 2017). It has been highlighted that humanitarian 
products are actually 'goods' which can only be valued while being consumed (Oloruntoba and Gray, 2009; Van Wassenhove, 2006). Even though humanitarian products have both immaterial and material components, their central characteristic are the ability to satisfy specific donor/beneficiary needs (Heaslip, 2013). Those involved in the distribution and receipt of humanitarian aid do not experience 'aid' as isolated, but interpret their value as tightly linked to their unique life situations. Thus, we can conclude that the serviceorientation is inherent in $\mathrm{HL}$ in terms of its interest in the use context and in customer collaboration. We have two goals in this conceptual article:

1. The first is to fill the gap in extant research, and explore servitization in HL.

2. The second goal is to investigate servitization as a management innovation in IHOs and plot a research agenda for humanitarian logistics scholars.

The paper is structured as follows. In the next section, we start by reviewing the extant literature on servitization as a management innovation. The next section provides a description of the systematic review protocols used in examining the literature followed by discussions of findings from the literature across the themes investigated. We then synthesize how servitization can be applied to HL, present an example of cash transfer payments, and provide an agenda of fresh research opportunities integrating servitization and HK before concluding the paper.

\section{Mapping theoretical perspectives of servitization in humanitarian logistics research.}

Systematic reviews differ from traditional narrative reviews by adopting a replicable, scientific and transparent process, in other words a detailed technology, that aims to minimize bias through exhaustive literature searches of published and unpublished studies and by 
providing an audit trail of the reviewers decisions, procedures and conclusions (Briner et al., 2009; Rousseau, 2006; Tranfield et al., 2003). Systematic reviews expose studies to rigorous methodological scrutiny. Within the SCM and logistics field it may be possible to conduct a quality assessment of the research articles by evaluating the fit between research methodology and research questions. However, SCM and logistics researchers usually rely on the implicit quality rating of a particular journal (McKinnon, 2013; Menachof et al., 2009), rather than formally applying any quality assessment criteria to the articles they include in their reviews (i.e. refereed journals are 'better' than practitioner journals). The difficulty in specifying and conducting quality assessments of studies is a major challenge in developing a systematic review methodology for management research (Denyer and Tranfield, 2009; Rousseasu et al., 2008).

The main goal of a systematic literature review is to make sense of a mass of often contradictory evidence in order to help both academics and practitioners to improve their decision-making and practice, narrowing the knowing-doing gap that exists between research and practice. A systematic review (Tranfield et al., 2003) involves five stages:

1. Planning the review;

2. Identifying and evaluating studies;

3. Extracting and synthesising data;

4. Reporting descriptive and thematic findings; and

5. Utilising the findings in order to inform research and practice.

In the planning review stage a review panel of 3 academics was formed. The aim was to “identify a need for the review, prepare a proposal and develop a review protocol" (Tranfield et al., 2003: 214). The second stage was to conduct the review. A mapping of the field of 
investigation was conducted to fully define the scope of the study, the data to be collected and the data collection process.

Our choice to review servitization in HL literature entailed one selection decision: We limited the review to double-blind reviewed journal articles published in this field's top-tier journals. We focusing on academic contributions that are considered established knowledge (Vega and Roussat, 2015) which are likely to make a significant impact on the field (Heaslip, 2013). Established influential journals tend to shape the theoretical and empirical work in a field by setting new horizons for inquiry within their frame of reference (Furrer et al. 2008).

A three-stage selection process to identify relevant articles from these journals was formulated. First, a search of all issues of these journals from 2013 to the latest issue of January 2018 that was available on-line on January 10th, 2018, using various electronic databases (Business Source Premier, JSTOR, Emerald Insight, and Science Direct). 2013 was chosen as the cut-off point, because the seminal article calling for an examination of services within humanitarian logistics, 'Services operations management and humanitarian logistics' by Heaslip (2013) was published at this time.

Consistent with prior approaches to identifying relevant articles, such as: Tranfield et al., (2003); and Rousseau et al., (2008), we performed keyword searches and retained those articles that contained the word 'Humanitarian' and/or any of the phrases 'Disaster', 'Emergency Management', 'Crisis Management', 'Services Management', 'Services', 'Servitization', 'Logistics Service Provider', ‘3PL', '4PL' 'LSP', 'third party', fourth party', 'Humanitarian Aid', 'Humanitarian Logistics', 'Humanitarian Operations' or 'Humanitarian Supply Chains', in either their titles, abstracts or full texts. Thirty-one articles were identified at this stage. 
To classify which of these 31 articles focused on servitization in HL, one of the authors coded and analysed the extent to which (if any) the article focused on servitization in humanitarian logistics by rating each article's title and abstract on separate four-point scales anchored at 'not at all' and 'clearly' (Nag et al. 2007). Twenty articles satisfied this requirement, and these were forwarded to the third stage, in which we looked at the number of citations each individual article received in order to maximize the relevance of the set of articles. Rather than using an arbitrary cut-off point (Keupp et al., 2012) of how many citations an article had to receive (which would place newer articles at a disadvantage), we compared the number of citations each article received with the average number of citations received by articles appearing in the respective year in the respective journal. Thus, 17 articles remained for analysis and Table 1 provides an overview of the articles included in the review. The following sections present the results of such analysis.

\section{$<$ Please insert Table 1 here $>$}

\section{Servitization as a management innovation}

Vandermerwe and Rada, (1988) introduced servitization as a 'value-added. activity, where services are added to supplement a product already supplied. Spring and Araujo (2013) and Oliva and Kallenberg (2003) proposed a structured progressive step-by-step approach to servitization, with the provider taking the initiative. Their research makes a clear distinction between products and services and assumes that firms can create value and then deliver it to customers. Martinez et al (2010) expanded this concept demonstrating that increasing levels of service and interaction with the customer be taken where the customer and supplier move toward servitization together. 
Utilising the concepts introduced by service-dominant logic, $\mathrm{Ng}$ et al., (2012) focused on service rather than product and services, describing it as a dynamic activity where value emerges as a result of co-creation between customer, provider, and suppliers. Dachs et al., (2012) found a U-shaped relationship between firm size and success of servitization, which indicates that organisations have advantages in servitization. The advantages for small companies are based on their flexibility and effective internal communication, which enable flexible reactions to new market opportunities.

Previous research has recognised, that some firms face significant challenges during servitization (Martinez et al., 2010; Brax, 2005) and may fail in their efforts (Neely, 2008; Gebauer et al., 2005). Neely (2008) found that servitised firms tend to declare bankruptcy more often and generate lower net profits as a percentage of revenues than pure manufacturing firms. Gebauer et al. (2005) observed that substantial investments in extending service business do not lead to the expected higher returns in all manufacturing firms. These results indicate that servitization may not be an efficient management innovation in all cases.

Baines et al. (2017) note that 22 articles were published on servitization between 1991 and 2000 but increased five-fold to 101 between 2001 and 2010. These articles came from the services marketing, service management, operations management, product-service systems (PSS), and service sciences domain and helped establish the servitization field. Regarding undeveloped streams of servitization research, Baines et al. (2017) consider there is a need for research on the impact of disruptive innovations and the dynamics of technology shifts, combined with broader environmental and social aspects of servitization in an external context. Internally, we need research on legal and financial frameworks that support 
advanced services, the roles and advantages of active manufacturing technology innovation regarding supporting services, and the social and collective dynamics of business leaders who influence the propensity to servitize. As regards process and content, research should focus on factors influencing the successful adoption of services, new business models, and paths to service business unit development. Finally, there is a need for research to investigate contextual conditions for servitization from a prescriptive orientation.

Further, the servitzation literature has identified three general motives behind servitization: (1) economic/financial, (2) strategic/competitive advantage, and (3) marketing/user needs. The economic/financial motives described in the literature include the pursuit of higher profit margins and stability of income (Gebauer and Friedli, 2005; Wise and Baumgartner, 1999) due to the resilience of services to economic cycles (Gebauer and Fleisch, 2007; Oliva and Kallenberg, 2003). Strategic motives are largely concerned with gaining competitive advantage. One of the main arguments is that services are difficult to imitate due to their invisible and labour dependent nature (Gebauer and Friedli, 2005; Oliva and Kallenberg, 2003). This means that services reduce the need to compete on the basis of cost (Neely, 2008). Frambach et al., (1997) argue that the value-add of services can enhance the customer value where, identical physical products are perceived as customised, which leads to an increase in the barriers to competitors (Baines et al., 2009). Services also create customer loyalty (Correa et al., 2007; Vandermerwe and Rada, 1988) while Baines et al. note "the customer can become dependent on the supplier" (2009: 558). Customers increasingly demand a variety of services (Vandermerwe and Rada, 1988), for example in the B-2-B context, focusing on core competencies is an additional reason for the need for external services (Oliva and Kallenberg, 2003). 
Various researchers have discussed the transition from products to service solutions (see Spring and Araujo, 2013; Paiola et al., 2013; Kowalkowski et al., 2011; Matthyssens and Vandenbempt, 2008). This research points to the requirement for companies to develop capabilities in order to design, sell and deliver services (service capabilities) and to integrate these services into customer-specific solutions (integration capabilities). Continuing the move from products to service solutions further departs from extending services in the customer activities (Paiola et al., 2013) and moves forward to taking over full responsibility for a customer's process (Kowalkowski et al., 2011) through outsourcing services (Oliva and Kallenberg, 2003), i.e. business process integration services (Matthyssens and Vandenbempt, 2008). Table 2 highlights the service and integration capabilities discussed in the literature.

$<$ Please insert Table 2 about here>

Service capabilities include establishing a service culture (Bowen et al., 1989) which, in turn, lays the foundation for increasing the degree of service orientation (Homburg et al., 2003). Technical expertise is required as an integral part of remote services, which collect data on the status, diagnostics and usage of the capital goods in question (Allmendiger \& Lombreglia, 2005). Oliva and Kallenberg (2003) argue that adequate pricing mechanisms rely on the ability of gathering information and monitoring the usage of the product. Pricing needs not only an estimation of the cost of delivering the service (Malleret, 2006) but also capabilities to assume the operating risk of the capital goods (Kindström, and Kowalkowski, 2014). Introducing new services requires capabilities that allow an in-depth understanding of the customers operational and business needs, so that the specific service component to be developed can be identified (Gebauer et al., 2005), the integration of external resources from a network (Spring and Araujo, 2013) and to develop new services systematically by means of 
a structured model (Rapaccini et al., 2013). Kowalkowski et al., (2011) highlight distribution channels as being essential when transitioning from products to service solutions.

When integrating services into customer-specific solutions, companies need to develop capabilities for understanding customer needs from a comprehensive perspective (Davies et al., 2007; 2006a; 2006b). Integrating a diverse set of product and service components requires multi-skilled and cross-functional competencies (Windahl and Lakemod, 2010; 2006), which include key account management, financial expertise, technical design expertise, communication expertise and project management (Neu and Brown, 2005).

In today's business, the focus is increasingly on value, especially the role of customers (Viljakainen and Toivonen, 2014; Bezerra Barquet, et al., 2013). The service-dominant logic (S-DL) (Vargo and Lusch, 2004, 2008) highlights the value-creating nature of consumption. S-DL points out that customers evaluate the value of goods and services not one by one, but holistically based on the combination of commodities: one commodity purchased from one provider is meaningful only when it is linked to other commodities (Viljakainen and Toivonen, 2014). By offering clients new value that goes beyond the conventional context organisations can increase their competitive advantage and profitable growth (Viljakainen and Toivonen, 2014; Gronroos, 2011; Kowalkowski et al., 2011). The value offerings arise from redefining clients' problems and discovering hidden demand (Matthyssens and Vandenbempt, 2008; Kim and Mauborgne, 1999). Supplementing own resources with resources from partner networks across industries is at the core of creating new customercentric solutions (Spring and Araujo, 2013; Bezerra Barquet, et al., 2013; Baines et al., 2009; Gebauer and Fleisch, 2007; Normann and Ramirez, 1993). 
Servitization is often presented as a strategic choice among larger companies delivering capital equipment and related services (Baines et al., 2009). Business in general has been developed around the dominant logic of tangible goods (Barnett et al., 2013). Firms believe that increasing services will deliver higher margins (Gebauer et al, 2005) and that offering services as well as products increases the level of differentiation (Vandermerwe and Rada, 1988). Similarly, Heaslip (2013) introduced service business development as a strategic choice for IHOs. A discussion about servitization in a HL context is provided next.

\section{Servitization in Humanitarian Logistics (HL)}

In logistics and operations literature, the perspective that is often taken is simply that of freight/cargo movement which Lusch and Vargo (2014: 2) refer to as transport of "the things and stuff that need to be transported, stored, and handled". Perspectives on and studies of the recipients of emergency and disaster relief and the beneficiaries of disaster management activities in the logistics literature are relatively few (see for example, Baharmand et al., 2017; Overstreet et al., 2011; Altay and Green, 2006). This is explained in part by the distinction between beneficiaries (end customers) and paying customers, as beneficiaries in the humanitarian context lack purchasing power and are rarely involved in purchasing decisions. Likewise, studies using a service lens focusing on services and the processes of service provision and management in the context of HL for emergency and disaster response are limited (Heaslip, 2015; Heaslip, 2013; Kovács and Spens, 2011).

Like Baines et al. (2017), Kunz et al. (2917) note the research in HL suffers from a lack of contextualization as humanitarian organizations are very specific and differ substantially from that in which commercial companies operate. Due to the unpredictable nature of disasters, logisticians in a humanitarian setting cannot rely on well-defined plans. One of 
their ten suggestions or "rules" for HL research is "knowing the specificities of the humanitarian context" which they consider "key to avoid selecting a non-relevant problem or making wrong assumptions" (2017: 1592).

However, there is a need for international humanitarian organisations (IHOs) to differentiate themselves, just as commercial companies do (Nurmala et al., 2017; Nätti et al., 2014; Oloruntoba and Gray, 2009. For example, many humanitarian organizations do exactly the same things (provide food, water, sanitation, shelter, health care, education) they seek funding and resources from the same donors (governments, institutional and private), they use the same mass media to raise awareness and funds; their marketing strategies are very similar; and they use the same transport carriers and logistics service providers (Cozzolino et al., 2017; Vega and Roussat, 2015; Heaslip, 2013). Consequently, whatever marketing strategies they employ are quickly copied by other IHOs, who in essence, are in competition (Nurmala et al., 2017; Oloruntoba and Gray, 2009; Shaw and Goda, 2004). Organizations trying to create or maintain differentiation in the humanitarian sector, often find that whatever changes they make are greeted by counter moves from competing relief organizations (Nurmala et al., 2017; Oloruntoba and Gray, 2009). For many IHOs the way to sustainable competitive advantage may not lie in changes in the product, promotion, or pricing strategies of the organization, but rather in improving customer service within HL, ancillary services, such as logistics and distribution (Nätti et al., 2014; Saglietto, 2013; Oloruntoba and Gray, 2009) and servitization (Heaslip, 2013).

A traditional concept of customer is the party that pays for goods or services, and is thus involved in a commercial transaction. Just as various segments of the target markets differ in customer requirements, customers in the humanitarian relief context have differing and 
varying requirements. However, an understanding of the complexity of the customer profile of IHOs could be a key towards understanding the servitization offering. Table 3 provides an overview of IHOs' customers.

$<$ Please insert Table 3 about here>

\subsection{Waves of servitization in $H L$}

Initially IHOs were defined around the products they delivered, such as World Food Programme (WFP) - food; International Federation of Red Cross and Red Crescent Societies (IFRC) - shelter and Medicines Sans Frontiers (MSF) - health. The Asian tsunami in December of 2004 and the response to the Darfur crisis in 2004/2005 demonstrated problems providing sufficient coverage in large relief operations (Jahre et al., 2015; Jahre and Jensen, 2010). A cluster approach was proposed as a way of addressing gaps and strengthening the effectiveness of humanitarian response. Product foci were used as the basis for structuring humanitarian response through the clusters (Abidi et al., 2015; Kovács and Spens, 2007). Originally there were nine clusters; Water, sanitation and hygiene (WASH), protection, nutrition, education, early recovery, emergency shelter, camp management, health, food security, and emergency telecommunications. To ensure the delivery of 'goods' for the clusters' 'common services' such as logistics were incorporated into the cluster system. The Logistics Cluster is responsible for coordination, information management, and, where necessary, logistics service provision to ensure an effective and efficient logistics response takes place in each and every operation (Holguín-Veras et al., 2013). To achieve this goal, the Logistics Cluster fills gaps in logistics capacity, meets the need for logistics coordination services, and where necessary acts as 'provider of last resort'. The introduction of the Logistics Cluster lead to the first wave of servitization in the humanitarian environment, WFP 
for example moved from a focus of delivering food to delivering services (Bealt et al., 2016; Heaslip, 2013; Jensen, 2012), see Table 4 for an overview of UNWFPs service offering.

\section{$<$ Please insert Table 4 about here>}

With this first wave of servitization, it is as if the goods an IHO provides had become a 'qualifier', whereas the service offered has become the 'order winner'. The focus has shifted from core products towards the services because offering a mixture of goods and services allows the IHO to differentiate and create a more satisfied and loyal customer - though with a focus on donors as customers, not beneficiaries. Table 5 shows the different types of IHOs and the move to more service offerings. The traditional view of an IHO is in providing tangible relief (such as water, food, and shelter). Examples of traditional IHOs include Oxfam and World Vision. Post the 2004 Asian tsunami the asset based IHO developed. This was primarily from the diversification of some traditional IHOs into more complex offerings. Several of the world's leading IHOs moved in this direction (for example United Nations Humanitarian Response Deport - UNHRD).

In the early 2000s a number of network based IHOs appeared, most notably United Nations Children's Fund (UNICEF) and WFP. This move by IHOs to offering value added services includes procurement services being offered by agencies such as the United Nations Children's Fund (UNICEF), the United Nations Humanitarian Response Deport (UNHRD) network and the United Nations Office for Project Services (UNOPS) to other UN agencies as well as to governments (Baharmand et al., 2017; Kovács, 2014). Procurement works like a pivot in the internal supply chain process turning around requests into actual products/commodities or services to fulfil the needs. Beyond the United Nations (UN) family, the IFRC have developed a procurement centre and procurement portal that has been 
accredited by the European Commission's Humanitarian Aid \& Civil Protection agency (ECHO), and through which third parties outside Red Cross/Red Crescent national chapters can ask for their services. Other value added services are also available, for example the IFRC is offering its services in areas such as 'procurement and transportation', 'warehousing and handling', 'contingency stock', 'fleet service' and 'insurance' (Kovács, 2014; IFRC, 2012). In addition to these, Heaslip (2013) has demonstrated the existence of further applications of service operations in humanitarian supply chains, for example the WFP acting as a consignee in major disasters and consolidating transportation, as well as service standardisation. The nature of these services necessitates creating geographically extensive and tightly integrated networks of operations, some of which might operate horizontally as Toyasaki et al. (2017) report as regards UNHRD. The development of 'common services' has even become one of four key points on the agenda of the Global Logistics Cluster meeting in Copenhagen in November 2014. The global strategy of the Logistics Cluster for 2013-2015 (GLC, 2013) includes the point of developing a 'service catalogue' that would be available for addressing and filling gaps in logistics services in risk areas but also to build national preparedness - albeit it remains disputed which role the cluster should play in the latter.

$<$ Please insert Table 5 about here>

The fourth type of IHO - the service revolution - has been a recent phenomenon. These are IHOs that provide a range of primarily information based services. These encompass consultancy services (including supply chain configuration) and training. Examples of this type of IHO include UNWFP, which has developed the Logistics Response Team Training (LRT training) that it has offered to other organisations in the Logistics Cluster since 2007. Interestingly, an integral part of this is a 'service mindset training' for logisticians. 
Service development has become the norm in humanitarian logistics (Cozzolino et al., 2017; Vega and Roussat, 2015; Heaslip; 2015). Incredibly many organisations can be included in just one delivery through service tiering; especially when it comes to cross-border operations in conflicts. Figure 1 depicts the various logistics service providers and co-operation or implementing partners in a cross-border delivery to a conflict zone where even vehicles need to be switched - and reloaded - at borders. This is a simple diagram for deliveries in the last mile, which can be much more complex if considering transportation consolidation, and the involvement of fourth party logistics providers, who are seen as providing solutions for various HL issues (Abidi et al., 2015), to freight forwarders in various steps in the material flow.

$<$ Please insert Figure 1 about here $>$

Table 6 applies Viljakainen and Toivonen's (2014) trend analysis to demonstrate how new trends impact on the increasing service orientation within HL and to the humanitarian setting. We now turn to discuss one trend, cash transfer payments (CTPs), as an example to illustrate how servitization would impact this trend through research and practice.

<Please insert Table 6 about here>

\subsection{An example of cash transfer payments (CTPS)}

Until now, the role of beneficiaries as customers in humanitarian operations has been disputed (Bealt et al., 2016; Holguín-Veras et al., 2013; Kovács and Spens, 2007; Van Wassenhove, 2006), not the least because of their lack of purchasing power. The traditional 
form of humanitarian relief has been to provide the people in need with goods. Beneficiaries in this model do not have voice in the type of goods procured or distributed to them (Matopoulos et al., 2014). However, humanitarian aid is shifting towards providing cashbased assistance instead of goods (Heaslip et al., 2018; Kovács, 2014), thus providing beneficiaries with purchasing power. This move from a product delivery to a cash delivery is the second wave of servitization.

Whilst the Global Logistics Cluster does not yet mention cash transfer programmes (CTPs) as part of its current strategy (GLC, 2015), the cluster lead has started to shift towards their implementation. The World Food Programme's (WFP) shift from food aid to food assistance in 2008 is evidence of the changing humanitarian landscape. WFP adopted a cost conscious approach to the global economic downturn that considers: value; accountability; alternative funding models (cash); justification of spending; capacity building; innovation and performance measurement tools (Heaslip et al., 2018).

The use of cash transfer programmes (CTPs) is on the rise, for example, between 2009 and 2014, the use of cash by the World Food Programme (WFP) increased from US\$10 million (less than 1 per cent of total aid) to US\$3 billion (IRIN, 2014) and by the start of 2016 it was estimated that cash-based programming accounted for more than 25 per cent of WFPs total spend on assistance (WFP, 2017). In 2000, UNHCR implemented 15 programs that relied on cash and cash-alternatives; by 2015 that number had increased to 60 programs, with a budget of approximately \$465 million (UNHCR, 2015).

Cash transfers shorten the supply chain, simplify procurement and remove the need for many HL activities such as transport and warehousing considerations which ultimately may shrink 
the humanitarian sector considerably (WFP, 2018). In short, a shift from material to financial flows diminishes the total cost of aid whilst simultaneously empowering beneficiaries (Heaslip et al., 2018; Kovács, 2014). Beneficiaries receive the full measure of the intended relief aid through cash transfers as opposed to selling in-kind aid which is sold at much less than the associated logistical costs in order to meet other needs (Bailey et al., 2008). Cash transfers fundamentally alter the balance of power between the donor and the beneficiary as it increases the freedom of beneficiaries to decide how to use the cash (Aker, 2013). This has meant that beneficiaries have changed from being passive beneficiaries to becoming active members of the humanitarian supply chain (Matopoulos et al., 2014). Cash transfers adhere to the oft cited principles of empowerment, dignity and choice for the beneficiaries (Bailey et al., 2008). The beneficiaries need to be consulted and given a participatory role in CTP programmes (Bailey et al., 2008), similar to the role of customers in a commercial supply chain.

Perhaps the most intriguing change is the impact on financial vs. material flows in the humanitarian supply chain. In the traditional model, financial flows originated from donors to IHOs, which used these finances to pay for material supplies that they delivered to beneficiaries (Heaslip et al., 2015). In CTPs, financial flows from donors still come to IHOs, which then assess the possibility for distributing cash directly to beneficiaries. If this is possible - given that there are items available on a market, for instance - the financial flows go directly to beneficiaries, who pay themselves for the products and services they need. Humanitarian organisations become the brokers of these flows, and the distributors of cash, but not the providers of materials. Their role in delivering materials diminishes to the materials that are not available on the local market. 
In the humanitarian contexts, CTPs speed up the delivery of aid, reduce the need for inventories and transportation capacity, and even allow beneficiaries to make their own choices rather than humanitarian organisations making these for them (Heaslip et al., 2015). For example, Ugandan mobile network operators MTN and Airtel are partnering with NGOs including Danish Church Aid (DCA), Mercy Corps and the International Rescue Committee to deliver digital cash to refugees. After the 2004 Indian Ocean tsunami the Sri Lankan Government made people open bank accounts to facilitate a CTP as did the Iranian government after the Bam earthquake in 2003 (Doocy et al., 2006).

There are a range of mechanisms used to deliver cash based responses to recipients, however, cash transfer programmes utilising mobile money can take one of three forms, a) fund transfer directly into the beneficiary's mobile account, b) fund transfer via a mobile voucher for the beneficiary to redeem (or cash-out) and c) fund transfer from a pre-determined purpose, such as buying food.

This also implies a significant change in supply chain strategy. The traditional humanitarian supply chain pushes items first and gradually moves towards a pull strategy once more information becomes available. Cash transfer programmes enable a pull strategy to be implemented from the beginning. Through this, arguably, they can meet the actual needs of beneficiaries quicker and more accurately.

Generally speaking, CTPs imply a reconfiguration of the humanitarian supply chain with consequential important contributions to the reinstatement of the local economy. In humanitarian supply chains where the main activity is providing physical goods, the actors conducting the activity of distribution are commonly a local implementing partner such as the 
local authorities or local nongovernmental organisation (NGO). Indeed, it is typically not IHOs but their local implementing partners that conduct the last mile distribution of aid in the field. In the distribution of CTPs, there is a shift for the role towards an actor that can better handle the financial flow. A pre-condition is still that there are functioning markets on location and that the beneficiary has access to that market. DG ECHO (2013), a major donor for IHOs, recently suggested a decision tree to support IHOs in their shaping of CTPs, outlining pre-conditions and even checklists for the move from providing items to starting to provide vouchers, to cash for work solutions, to, ultimately, unconditional cash transfers.

This form of humanitarian assistance has since become more popular and new telecommunication solutions for cash transfers such as "mobile money" launched by organisations such as Safaricom have enabled their use in various African countries (Kovács, 2014).

\section{Summary of research agenda}

Overall, the first and second wave of servitization leave a number of questions open for further research. First, CTPs require that:

- The goods needed by beneficiaries are available on the local market,

- A (mobile) banking system exists, and has prevailed in the aftermaths of a disaster, and

- Beneficiaries have access to markets and can be reached through the banking system.

Second, as regards IHOs, the impact is not a straightforward one. IHOs will need to continue carrying out needs assessments, and capability-vulnerability assessments of beneficiaries as before. In other words, they need to establish who needs what in the aftermaths of a disaster. 
But now more than before, IHOs also need to be able to assess the capabilities of the local and regional markets. Disasters typically disrupt markets and destabilise infrastructure - from transport to energy to communications infrastructure. In combination, the question is not only one of the availability of items on the local market but also the upkeep of supplies in the longer run. Hence a first question is which goods would still need to be delivered by IHOs, whereas which others could be replaced with a financial flow and CTPs.

Third, at the same time stable electricity supplies are a typical requirement for both mobile communications and banking. The absence of electricity often shuts banks down in the aftermaths of a disaster, which is why humanitarian logisticians typically carry cash for paying suppliers, logistics service providers, and staff. This does not necessarily render CTPs impossible but require alternative solutions such as voucher systems. IHOs will though need to be able to make the assessment whether any banking system exists and is reliable, whether it reaches beneficiaries, or whether there is a need for alternative systems. This alters the requirements on the IHO's capabilities, and also, the requirements on its implementing partners.

Fourth, even items the IHO needs to deliver in the immediate aftermath of a disaster could reach markets through different channels once the infrastructure has been stabilised. In this case, the question is for how long IHO support is needed in the form of goods, and at which point it can be turned to cash instead. Further research is needed on all of these points.

In summary, as noted in several studies (Tan et al., 2009; Olivia and Kallenberg, 2003) moving from pure product to more service-oriented offerings, similar to the shift explored in product service systems (PSS), covers several linear steps (Smith et al., 2012; Johnstone et 
al., 2009; Vargo and Lusch, 2004). Olivia and Kallenberg (2003) suggested the 'gradual transformation process' to service provision, defining the start point with sole product offerings gradually expanded to pure service solutions and a combination of product-service value propositions in the middle of the transition. This area of product-service mix has rarely been examined in the context of humanitarian operations and may provide scholars with opportunities to revise the product-service model.

\section{Conclusion}

This paper is conceptual - its purpose is to provide a research agenda for humanitarian logistics scholars. It thus initiates a discourse on the importance of taking into account servitization in developing and managing effective emergency relief chains. We argue that a broader servitization paradigm needs integration with HL for IHOs to maintain a competitive advantage. This is due to the current manufacturing-based paradigm focusing almost exclusively on tangible relief products and associated 'freight' transport and storage when in fact, the practice of humanitarian logistics for disaster response and management has shifted in the direction of providing services, and as of late, cash or vouchers (Kovács, 2014; Heaslip, 2013; IFRC, 2012). Now, the execution of activities, such as deliveries, repair and maintenance, customer training, problem recovery, invoicing, can be incorporated into the service process (Grönroos, 2011).

This study has contributed to the servitization literature by increasing the understanding of how servitization is adopted by IHOs in HL and identifying outstanding issues for further research. The paper also presents a research agenda for HL scholars. By examining the humanitarian environment scholars may be able to develop new servitization offerings and find an effective way of "adding value" to humanitarian and commercial organisations. 
This paper highlights a business shift towards a new more customer oriented value proposition to satisfy the changing requirements within the humanitarian sector. Services provision plays a crucial role for new product introduction such as CTPs providing a new product creation. Recently, HL is providing greater attention to customer needs and deeper analysis of customer operations.

\section{References}

Abbasi, M-A., and Liu, H. (2013), "Measuring user credibility in social media", Social Computing, Behavioral-Cultural Modeling and Prediction, Lecture Notes in Computer Science, Vol. 7812, pp. 441-448.

Abidi, H., de Leeuw, S. and Klumpp, M. (2015), "The value of fourth-party logistics services in the humanitarian supply chain", Journal of Humanitarian Logistics and Supply Chain Management, Vol. 5 No. 1, pp.35-60.

Aker, J., (2013) Cash or Coupons? Testing the Impacts of Cash versus Vouchers in the Democratic Republic of Congo - Working Paper 320, Center for Global Development, Available at: http://www.cgdev.org/publication/cash-or-coupons-testing-impacts-cashversus-vouchers-democratic-republic-congo-working (accessed 8 April 2014).

Allmendiger, G., \& Lombreglia, R. (2005). Four Strategies for the Age of Smart Services. Harvard Business Review, 131-145.

Altay, N. and Green, W.G. (2006). OR/MS research in disaster operations management, European Journal of Operational Research, 175(1), 475-493.

Auramo, J. and Ala-Risku, T. (2005), "Challenges for going downstream", International Journal of Logistics: Research and Applications, Vol. 8 No. 4, p. 333.

Bag, S., (2016) Humanitarian supply chain management: A bibliometric analysis of the literature, AIMS International Journal of Management, Vol 10, No. 3, pp.175-202.

Baharmand, H., Comes, T. and Lauras, M. (2017), "Managing in-country transportation risks in humanitarian supply chains by logistics service providers: Insights from the $2015 \mathrm{Nepal}$ earthquake", International Journal of Disaster Risk Reduction, Vol. 24, pp. 549-559.

Bailey, S., Savage, K. \& O'Callaghan, S. (2008). Cash Transfers in Emergencies: A Synthesis of World Vision's Experience and Learning. London, UK: Humanitarian Policy Group at Overseas Development Institute.

Baines, T., Bigdeli, A.Z., Bustinza, O.F., Shi, V.G., Baldwin, J. and Ridgway, K. (2017) "Servitization: revisiting the state-of-the-art and research priorities", International Journal of Operations \& Production Management, Vol. 37 Iss: 2, pp.256-278.

Baines, T.S., Lightfoot, H. W., Benedettini O., and Kay, J. M., (2009),"The servitization of manufacturing", Journal of Manufacturing Technology Management, Vol. 20 Iss 5 pp. 547 $-567$.

Barnett, N. J., Parry, G., Saad, M., Newnes, L. B., and Goh, Y. M., (2013). Servitization: Is a Paradigm Shift in the Business Model and Service Enterprise Required?, Strategic Change, Vol. 22, pp. 145-156 
Bask, A. H., Tinnilä, M., \& Rajahonka, M. (2010). Matching service strategies, business models and modular business processes, Business Process Management Journal, 16 (1), 153-180.

Bealt, J., Fernandez Barrera, J.C., and Mansouri, S.A. (2016), "Collaborative relationships between logistics service providers and humanitarian organizations during disaster relief operations", Journal of Humanitarian Logistics and Supply Chain Management, Vol. 6 No. 2, pp. 118-144.

Bezerra Barquet, A. P., de Oliveira, M. G., Amigo, C. R., Cunha, V. P., and Rozenfeld, H., (2013), Employing the business model concept to support the adoption of product-service systems (PSS), Industrial Marketing Management, Vol. 42, pp. 693-704.

Bowen, D., Siehl, C., \& Schneider, B. (1989). A framework for analyzing customer service orientations in manufacturing. Academy of Management Review, 14(1), 75-95.

Brax, S. (2005), "A manufacturer becoming service provider - challenges and a paradox", Manufacturing Service Quality, Vol. 15 No. 2, pp. 142-56.

Charles, A., and Lauras, M., (2011) "An enterprise modelling approach for better optimisation modelling: application to the humanitarian relief chain coordination problem", OR Spectrum, Vol 33, Iss, 3, pp. 815-841.

Chiappetta Jabbour, C.J., Sobreiro, V.A., Lopes de Sousa Jabbour, A.B., de Souza Campos, L.M., Barberio Mariano, E. and Renwick, D.W. (2017), "An analysis of the literature on humanitarian logistics and supply chain management: paving the way for future studies", Annals of Operations Research, pp. 1-19.

Correa, H.L., Ellram, L.M., Scavarda, A.J. and Cooper, M.C. (2007), "An operations management view of the service and goods mix", International Journal of Operations \& Production Management, Vol. 27 No. 5, pp. 444-63.

Cozzolino, A., Wankowicz, E. and Massaroni, E. (2017), "Logistics service provider's engagement in disaster relief initiatives: An exploratory analysis", International Journal of Quality and Service Sciences, Vol.9 Issue 3/4, pp.269-291.

Craighead, C.W., Hanna, J.B., Gibson, B.J. \& Meredith, J.R. (2007). Research approaches in logistics: trends and alternative future directions, International Journal of Logistics Management, 18(1), 22-40.

Dachs, B., Borowiecki, M., Kinkel, S., Schmall, T.C., (2012). The off-shoring of production activities in European manufacturing. MPRA Paper Nr 42973.

Davies, A., Brady, T. \& Hobday, M. (2006b). Charting a path towards integrated solutions, MIT Sloan Management Review, 43(7), 39-48.

Davies, A., Brady, T. and Hobday, M. (2006a), "Organizing for solutions: systems sellers vs systems integration”, Industrial Marketing Management, Vol. 36, pp. 183-93.

Davies, A., Brady, T., \& Hobday, M. (2007). Organizing for solutions: Systems seller vs. systems integrator. Industrial Marketing Management, 36, 183-193.

DG ECHO (2013), Cash and Vouchers: Increasing efficiency and effectiveness across all sectors, Thematic Policy Document No.3, at http://ec.europa.eu/echo/files/policies/sectoral/them_policy_doc_cashandvouchers_en.pdf (accessed Feb 19, 2015)

DG ECHO (2014), Cash and vouchers, at http://documents.wfp.org/stellent/groups/public/documents/communications/wfp265227.p df (accessed Feb 19, 2015)

Doocy, S., Gabriel, M., Collins, S., Robinson, C., \& Stevenson, P. (2006) 'Implementing Cash for Work Programmes in Post-Tsunami Aceh'. Disasters, 30(3): pp.277-296.

Dufour, E., Laporte, G., Paquette, J. and Rancourt, M-E. (2018), "Logistics service network design for humanitarian response in East Africa", Omega, Vol. 74, pp. 1-14. 
Frambach, R., Wels-Lips, I. and Gundlach, A. (1997), "Proactive product service strategies an application in the European health market", Industrial Marketing Management, Vol. 26, pp. 341-52.

Gebauer, H. and Fleisch, E. (2007), "An investigation of the relationship between behavioural processes, motivation, investments in the service business and service revenue", Industrial Marketing Management, Vol. 36, pp. 337-48.

Gebauer, H. and Friedli, T. (2005), "Behavioural implications of the transition process from products to services", Journal of Business \& Industrial Marketing, Vol. 20 No. 2, pp. 7080 .

Gebauer, H., Fleisch, E., \& Friedli, T. (2005). Overcoming the service paradox in manufacturing companies. European Management Journal, 23(1), 14-26.

GLC (2013). Global Strategy 2013-2015. Logistics Cluster, at http://www.logcluster.org/sites/default/files/logistics_cluster_glcsc_strategic_plan_20122015_0.pdf (accessed Feb 19, 2015).

Grönroos, C. (2011). A service perspective on business relationships: The value creation, interaction and marketing interface. Industrial Marketing Management, 40(2), 240-247.

Gummesson, E. (1995). Relationship marketing: Its role in the service economy. In William J. Glynn, \& James G. Barnes (Eds.), Understanding Services Management (pp. 244-268). New York: Wiley.

Gupta, S., Verma, R. \& Victorino, L. (2006). Empirical research published in Production and Operations Management (1992-2005): Trends and future research directions, Production and Operations Management, 15(3), 432-448.

Heaslip, G. (2013), "Services operations management and humanitarian logistics", Journal of Humanitarian Logistics and Supply Chain Management, Vol. 3 No.1, pp. 37-51.

Heaslip, G., (2015) 'Humanitarian Logistics - An Opportunity for Service Research, Journal of Humanitarian Logistics and Supply Chain Management, Vol. 5, Iss. 1, pp.2-11.

Heaslip, G., Haavisto, I., and Kovács, K., (2015), Cash as a form of relief, in Zobel, C., Altay, N., and Haselkorn, M., (eds), Advances in Managing Humanitarian Operations, International Series in Operations Research \& Management Science, Springer, pp.59-78.

Heaslip, G., Kovács, G., Haavisto, I., (2018) "Cash-based response in relief: the impact for humanitarian logistics", Journal of Humanitarian Logistics and Supply Chain Management, https://doi.org/10.1108/JHLSCM-08-2017-0043

Holguín-Veras, J., Pérez, N., Jaller, M., Van Wassenhove, L. N., and Aros-Vera, F., (2013), On the appropriate objective function for post-disaster humanitarian logistics models, Journal of Operations Management, 31, pp.262-280.

Homburg, C., Fassnacht, M., \& Guenther, C. (2003). The role of soft factors in implementing a service-oriented strategy in industrial marketing companies. Journal of Business-toBusiness Marketing, 10(2), 23-51.

Imran, M., Elbassuoni, S., Castillo, C., Diaz, F., and Meier, P. (2013), "Extracting information nuggets from disaster-related messages in social media", ISCRAM conference 2013, Baden-Baden, Germany.

International Federation of Red Cross and Red Crescent Societies (IFRC), (2012), Logistics Preparedness, Available at: http://www.ifrc.org/en/what-we-do/disastermanagement/preparing-for-disaster/disaster-preparedness-tools/logistics-preparedness [Accessed 14/04/14]

IRIN (2014) Latest innovations in cash transfers, Available at: http://www.irinnews.org/feature/2014/07/31/latest-innovations-cash-transfers [Accessed January 18, 2018]

Jacob, F., and Ulaga, W. (2008). The transition from product to service in business markets: An agenda for academic inquiry. Industrial Marketing Management, 37(3), 247-253. 
Jahre, M., and Jensen, L. M., (2010), "Coordination in humanitarian logistics through clusters", International Journal of Physical Distribution and Logistics Management, Vol. 40 No. 8/9, pp, 657-674.

Jahre, M., Ergun, O. and Goentzel, J. (2015), “One size fits all? Using standard global tools in humanitarian logistics", Procedia Engineering, Vol. 107, pp. 18-26.

Jensen, L-M (2012), "Humanitarian cluster leads: lessons from 4PLs", Journal of Humanitarian Logistics and Supply Chain Management, Vol. 2 No. 2, pp. 148-160.

Johnstone, S., Dainty, A. and Wilkinson, A., (2009) "Integrating products and services through life: an aerospace experience", International Journal of Operations \& Production Management, Vol. 29 No. 5, pp.520 - 538.

Kim, W. C., and Mauborgne, R. (1999). Strategy, value innovation, and the knowledge economy. Sloan Management Review, 40(3), 41-54.

Kindström, D., \& Kowalkowski, C. (2014). Service innovation in product-centric firms: a multidimensional business model perspective. Journal of Business \& Industrial Marketing, 29(2), 96-111.

Kovács, G. (2014), "Where next? The future of humanitarian logistics". In: Christopher, Martin and Tatham, Peter (eds.): Humanitarian Logistics: Meeting the Challenge of Preparing for and Responding to Disasters, 2nd edn., Kogan Page, London, UK, pp.275285.

Kovács, G. and Spens, K. (2007), "Humanitarian logistics in disaster relief operations", International Journal of Physical Distribution \& Logistics Management, Vol. 37 No. 2, pp. 99-114.

Kovács, G., and Spens, K. M. (2009), "Identifying Challenges In Humanitarian Logistics", International Journal of Physical Distribution and Logistics Management, Vol. 39, No. 6, Pp. 506-528.

Kovács, G., and Spens, K.M. (2011) "Trends and developments in humanitarian logistics - a gap analysis", International Journal of Physical Distribution and Logistics Management, Vol. 41 No. 1, pp. 32-45.

Kowalkowski, C., Kindström, D., and Witell, L. (2011b). Internalisation or externalisation? Examining organisational arrangements for industrial services, Managing Service Quality, 21(4), 373-391.

Kunz, N., and Reiner, G. (2012), "A meta-analysis of humanitarian logistics research", Journal of Humanitarian Logistics and Supply Chain Management, Vol.2 No. 2, pp. 116-147.

Leiras, A., deBrito, I Jr., Queiroz Peres, E., Rejane Bertazzo, T., Tsugunobu Yoshida Yoshizaki, H., (2014) Literature review of humanitarian logistics research: trends and challenges, Journal of Humanitarian Logistics and Supply Chain Management, Vol. 4 No. 1, pp. 95-130.

Lusch, R. F., and Vargo, S. L. (2014). Service-dominant logic: Premises, perspectives, possibilities. Cambridge: Cambridge University Press.

Machuca, J.D., del Mar Gonzalez-Zamora, M., \& Aguilar-Escobar, V.G., 2007. Service operations management research, Journal of Operations Management, 25, 585-603.

Malleret, V. (2006), "Value creation through service offers", European Management Journal, Vol. 24 No. 1, pp. 106-16.

Martinez V, Bastl M, Kingston J, Evans S. 2010. Challenges in transforming manufacturing organisations into product service providers. Journal of Manufacturing Technology Management 21(4): 449-469.

Matopoulos, A., Kovacs, G., and Hayes, O. (2014). Local resources and procurement practices in humanitarian supply chains: An empirical examination of large scale house reconstruction projects. Decision Sciences. Vol. 45, No. 4, pp. 621-646. 
Matopoulos, A., M. Vlachopoulou, and V. Manthou. (2007). "Exploring the Impact of ebusiness Adoption on Logistics Processes: Empirical Evidence from the Food Industry." International Journal of Logistics Research and Applications 10 (2): 109-122.

Matthyssens, P., \& Vandenbempt, K. (2008). Moving from basic offerings to value-added solutions: Strategies, barriers and alignment. Industrial Marketing Management, 37(3), 316-328.

Natarajarathinam, M., Capar, I. \& Narayanan, A. (2009). Managing supply chains in times of crisis: a review of literature and insights, International Journal of Physical Distribution \& Logistics Management, 39(7), 535-573.

Nätti, S., Hurmelinna-Laukkanen, P., Johnston, W. J., (2014) "Absorptive capacity and network orchestration in innovation communities - promoting service innovation", Journal of Business \& Industrial Marketing, Vol. 29 Issue: 2, pp.173-184.

Neely, A. (2008). Exploring the financial consequences of the servitization of manufacturing. Operations Management Research, 1(2), 103-118.

Neu, W. and Brown, S. (2005), "Forming successful business-to-business services in goodsdominant firms", Journal of Service Research, Vol. 8 No. 1, pp. 3-16.

Ng I, Parry G, Smith L, Maull, R, Briscoe, G. (2012). Transitioning from goods dominant to a service dominant logic visualising the value proposition of Rolls Royce. Journal of Service Management Issue 23(3): 416-439.

Normann, R. and Ramirez, R. (1993). From value chain to value constellation: Designing interactive strategy, Harvard Business Review, 71, 65-77.

Nurmala, N., de Leeuw, S., Dullaert, W., (2017) "Humanitarian-business partnerships in managing humanitarian logistics", Supply Chain Management: An International Journal, Vol. 22 Issue: 1, pp.82-94.

Oliva, R., and Kallenberg, R., (2003),"Managing the transition from products to services", International Journal of Service Industry Management, Vol. 14 Iss 2 pp. 160-172

Oloruntoba, R. \& Gray, R. (2009). Customer service in emergency relief chains, International Journal of Physical Distribution \& Logistics Management, 39(6), 486-505.

Overstreet, R.E., Hall, D., Hanna, J.B. \& Rainer, R.K. Jr (2011). Research in humanitarian logistics, Journal of Humanitarian Logistics and Supply Chain Management, 1(2), 114131.

Paiola, M., Saccani, N., Perona, N., and Gebauer, H., (2013), Moving from products to solutions: Strategic approaches for developing capabilities, European Management Journal, Vol. 31, pp.390-409.

Pedraza Martinez, A. and Van Wassenhove, L. N., (2011), Vehicle replacement in the International Committee of the Red Cross, Production and Operations Management, Vol. 22, No. 2, pp.365-376.

Pedraza Martinez, A. J., Stapleton, O., Van Wassenhove, L. N., (2011), Field vehicle fleet management in humanitarian operations: A case-based approach, Journal of Operations Management, 29, 404-421.

Prockl, G., Pflaum, A. and Kotzab, H. (2012), “3PL factories or lernstatts? Value-creation models for 3PL service providers", International Journal of Physical Distribution \& Logistics Management, Vol. 42 No. 6, pp. 544-61.

Raddats, C., \& Easingwood, C. (2010). Services growth options for B2B product-centric businesses. Industrial Marketing Management, 39(8), 1334-1345.

Rapaccini, M., Saccani, N., Pezzotta, G., Burger, T., \& Ganz, W. (2013). Service development in product-service systems: a maturity model. The Service Industries Journal, 33(3-4), 300-319.

Saglietto, L. (2013), "Towards a classification of fourth party logistics (4PL)", Universal Journal of Industrial and Business Management, Vol. 1 No. 3, pp. 104-116. 
Shaw, R. and Goda, K. (2004), "From disaster to sustainable civil society: the Kobe experience", Disasters, Vol. 28 No. 1, pp. 16-40.

Sheppard, A., Tatham, P., Fisher, R and Gapp, R (2013), "Humanitarian logistics: enhancing the engagement of local populations", Journal of Humanitarian Logistics and Supply Chain Management, Vol. 3 No.1, pp.22 - 36.

Skjoett-Larsen, T., Schary, P.B., Hsuan Mikkola, J. and Kotzab, H. (2007), Managing the Global Supply Chain, 3rd ed., Copenhagen Business School Press, Copenhagen.

Slack, N. (2005), "Operations strategy: will it ever realise its potential", Gestao \& Producao, Vol. 12 No. 3, pp. 323-32.

Smith, L., Maull, R., and Ng, I.C.L, "Servitization and Operations Management: A Service Dominant Logic Approach", International Journal of Operations \& Production Management, Vol. 34 No. 2, pp. 242-269.

Spring, M., Araujo, L., 2013. Beyond the service factory: Service innovation in manufacturing supply networks, Industrial Marketing Management, 42 (1), 59-70.

Tan, A., McAloone, T., and Matzen, D., 2009. "Service- Oriented Strategies for Manufacturing Firms", Introduction to Product/ Service-System Design, part 3, Springer, pp.197-218.

Taylor, A. and Taylor, M. (2009). Operations management research: contemporary themes, trends and potential future directions, International Journal of Operations \& Production Management, 29(12), 1316-1340.

Thomas, A. and Mizushima, M., 2005. Logistics training: necessity or luxury? Forced Migration Review, 22, 60-61.

Toyasaki, F., Arikan, E., Silbermayr, L. and Sigala, I.F. (2017), ”Disaster relief inventory management: Horizontal cooperation between humanitarian organisations", Production and Operations Management, Vol. 26 Iss: 6, pp. 1221-1237.

UNHCR (2015), Innovation: Cash-based interventions, Available at: http://www.unhcr.org/5596441c9.pdf [Accessed December 12, 2017]

Van Wassenhove, L.N. (2006), "Humanitarian aid logistics: supply chain management in high gear", Journal of the Operations Research Society, Vol.57, pp.475-489.

Vandermerwe, S. and Rada, J. (1988). Servitization of business: adding value by adding services, European Management Journal, 6(4), 314-324.

Vargo, S. L., \& Lusch, R. F. (2008). Service-dominant logic: Continuing the evolution. Journal of the Academic Marketing and Science, 36, 1-10.

Vargo, S.L. and Lusch, R.F. (2004). Evolving to a new dominant logic for marketing, Journal of Marketing, 68(1), 1-17.

Vega, D. and Roussat, C. (2015) "Humanitarian Logistics: The role of Logistics Service Providers", International Journal of Physical Distribution \& Logistics Management, Vol. 45 No. 4, pp. 352-375.

Viljakainen, A., and Toivonen, M., (2014). The futures of magazine publishing: Servitization and co-creation of customer value, Futures, Vol. 64, pp. 19-28.

Visnjic Kastalli, I. and Van Looy, B., (2013). Servitization: Disentangling the Impact of Service Business Model Innovation on Manufacturing Firm Performance. Journal of Operations Management 31(4): 169-180.

Windahl, C., and Lakemond, E. (2010). Integrated solutions from a service-centered perspective: Applicability and limitations in the capital goods industry. Industrial Marketing Management, 39(8), 1278-1290.

Windahl, C., and Lakemond, N. (2006). Developing integrated solutions: The importance of relationships within the network. Industrial Marketing Management, 35(7), 806-818.

Wise, R. and Baumgartner, P. (1999), "Go downstream: the new profit imperative in manufacturing”, Harvard Business Review, September/October, pp. 133-41. 
World Food Programme, (2013a). Impact evaluation of the targeted food and cash transfer programme (August 2012-March 2013). Lilongwe: WFP.

World Food Programme, (2013b). The World Food Programme's achievements in 2013, at http://documents.wfp.org/stellent/groups/public/documents/communications/wfp265227.p df (accessed Feb 10, 2015).

World Food Programme, (2017). WFP Strategic Plan, 2017-2021, Available at: https://docs.wfp.org/api/documents/WFP0000019573/download/?_ga=2.54782434.850199 635.1503717212-1544348492.1503717212 [Accessed January 18, 2018]

World Food Programme, (2018). Syria Emergency http://www1.wfp.org/emergencies/syriaemergency [Accessed Feb 10, 2018]

Zacharia, Z.G., Sanders, N.R. and Nix, N.W. (2011), "The emerging role of the third-party logistics provider (3PL) as an orchestrator", Journal of Business Logistics, Vol. 32 No.1, pp. 40-54. 


\begin{tabular}{|c|c|c|c|}
\hline Year & Author & Journal Title & Article Title \\
\hline 2018 & Dufour, Laporte, Paquette and Rancourt & Omega & $\begin{array}{l}\text { Logistics service network design } \\
\text { for humanitarian response in East Africa }\end{array}$ \\
\hline 2018 & Heaslip, Kovács and Haavisto & $\begin{array}{l}\text { Journal of Humanitarian Logistics and Supply } \\
\text { Chain Management }\end{array}$ & $\begin{array}{l}\text { Cash-based response in relief: the impact for } \\
\text { humanitarian logistics }\end{array}$ \\
\hline 2017 & Baharmand, Comes and Lauras & International Journal of Disaster Risk Reduction & $\begin{array}{l}\text { Managing in-country transportation risks in } \\
\text { humanitarian supply chains by logistics service } \\
\text { providers: Insights from the } 2015 \text { Nepal earthquake }\end{array}$ \\
\hline 2017 & $\begin{array}{l}\text { Chiappetta, Sobreiro, Lopes de Sousa } \\
\text { Jabbour, de Souza Campos, Barberio } \\
\text { Mariano and Renwick }\end{array}$ & Annals of Operations Research & $\begin{array}{l}\text { An analysis of the literature on humanitarian logistics } \\
\text { and supply chain management: paving the way for } \\
\text { future studies }\end{array}$ \\
\hline 2017 & Cozzolino, Wankowicz and Massaroni & $\begin{array}{l}\text { International Journal of Quality and Service } \\
\text { Sciences }\end{array}$ & $\begin{array}{l}\text { Logistics service provider's engagement in disaster } \\
\text { relief initiatives: An exploratory analysis }\end{array}$ \\
\hline 2017 & Nurmala, de Leeuw and Dullaert & $\begin{array}{l}\text { Supply Chain Management: An International } \\
\text { Journal }\end{array}$ & $\begin{array}{l}\text { Humanitarian-business partnerships in managing } \\
\text { humanitarian logistics }\end{array}$ \\
\hline 2016 & Bealt, Fernandez Barrera and Mansouri & $\begin{array}{l}\text { Journal of Humanitarian Logistics and Supply } \\
\text { Chain Management }\end{array}$ & $\begin{array}{l}\text { Collaborative relationships between logistics service } \\
\text { providers and humanitarian organizations during } \\
\text { disaster relief operations }\end{array}$ \\
\hline 2016 & Bag & AIMS International Journal of Management & $\begin{array}{l}\text { Humanitarian supply chain management: A } \\
\text { bibliometric analysis of the literature }\end{array}$ \\
\hline 2015 & Abidi, de Leeuw and Klumpp & $\begin{array}{l}\text { Journal of Humanitarian Logistics and Supply } \\
\text { Chain Management }\end{array}$ & $\begin{array}{l}\text { The value of fourth-party logistics services in the } \\
\text { humanitarian supply chain }\end{array}$ \\
\hline 2015 & Heaslip & $\begin{array}{l}\text { Journal of Humanitarian Logistics and Supply } \\
\text { Chain Management }\end{array}$ & $\begin{array}{l}\text { Humanitarian Logistics - An Opportunity for Service } \\
\text { Research }\end{array}$ \\
\hline 2015 & Jahre, Ergun and Goentzel & Procedia Engineering & $\begin{array}{l}\text { One size fits all? Using standard global tools in } \\
\text { humanitarian logistics }\end{array}$ \\
\hline 2015 & Vega and Roussat & $\begin{array}{l}\text { International Journal of Physical Distribution \& } \\
\text { Logistics Management }\end{array}$ & $\begin{array}{l}\text { Humanitarian Logistics: The role of Logistics Service } \\
\text { Providers }\end{array}$ \\
\hline
\end{tabular}




\begin{tabular}{|c|l|l|l|}
\hline 2014 & $\begin{array}{l}\text { Nätti, Hurmelinna-Laukkanen and } \\
\text { Johnston }\end{array}$ & Journal of Business \& Industrial Marketing & $\begin{array}{l}\text { Absorptive capacity and network orchestration in } \\
\text { innovation communities - promoting service } \\
\text { innovation }\end{array}$ \\
\hline 2014 & $\begin{array}{l}\text { Leiras, deBrito, Queiroz Peres, Rejane } \\
\text { Bertazzo and Tsugunobu Yoshida } \\
\text { Yoshizaki }\end{array}$ & $\begin{array}{l}\text { Journal of Humanitarian Logistics and Supply } \\
\text { Chain Management }\end{array}$ & $\begin{array}{l}\text { Literature review of humanitarian logistics research: } \\
\text { trends and challenges }\end{array}$ \\
\hline 2013 & $\begin{array}{l}\text { Holguín-Veras, Pérez, Jaller, Van } \\
\text { Wassenhoveand Aros-Vera }\end{array}$ & Journal of Operations Management & $\begin{array}{l}\text { On the appropriate objective function for post-disaster } \\
\text { humanitarian logistics models }\end{array}$ \\
\hline 2013 & Saglietto & $\begin{array}{l}\text { Universal Journal of Industrial and Business } \\
\text { Management }\end{array}$ & Towards a classification of fourth party logistics (4PL) \\
\hline 2013 & Sheppard, Tatham, Fisher and Gapp & $\begin{array}{l}\text { Journal of Humanitarian Logistics and Supply } \\
\text { Chain Management }\end{array}$ & $\begin{array}{l}\text { Humanitarian logistics: enhancing the engagement of } \\
\text { local populations }\end{array}$ \\
\hline
\end{tabular}

Table 1: Articles included in the review 


\begin{tabular}{|c|c|c|}
\hline & Capabilities & Authors \\
\hline \multirow[t]{6}{*}{ Service Capabilities } & Service culture & Bowen et al., 1989 \\
\hline & Service orientation & Homburg et al., 2003 \\
\hline & Technical expertise & $\begin{array}{l}\text { Matthyssens and Vandenbempt, } \\
2008 \text {; Allgendiger and } \\
\text { Lombrglia, 2005 }\end{array}$ \\
\hline & Pricing mechanism & $\begin{array}{l}\text { Kindström, and Kowalkowski, } \\
\text { 2014; Oliva and Kallenberg, } \\
2003\end{array}$ \\
\hline & Organisational structure & $\begin{array}{l}\text { Rapaccini et al., 2013; Gebauer } \\
\text { et al., } 2005\end{array}$ \\
\hline & Distribution channels & $\begin{array}{l}\text { Kowalkowski et al., 2011; } \\
\text { Malleret, 2006 }\end{array}$ \\
\hline \multirow[t]{3}{*}{ Integration Capabilities } & Understanding customer needs & $\begin{array}{l}\text { Paiola et al., 2013; Davies et al., } \\
\text { 2007; 2006a; 2006b }\end{array}$ \\
\hline & $\begin{array}{l}\text { Identifying and using external } \\
\text { resources from a network }\end{array}$ & Spring and Araujo, 2013 \\
\hline & $\begin{array}{l}\text { Multi-skilled and cross } \\
\text { functional competencies }\end{array}$ & $\begin{array}{l}\text { Windahl and Lakemod, 2006, } \\
\text { 2010; Neu and Brown, 2005 }\end{array}$ \\
\hline
\end{tabular}

Table 2: Service capabilities and integration capabilities

Source: adapted and extended from Paiola et al., 2013 


\begin{tabular}{|c|c|c|c|}
\hline Actor & Function & $\begin{array}{c}\text { Commercial } \\
\text { transaction }\end{array}$ & Authors \\
\hline Beneficiaries & $\begin{array}{l}\text { The end-user of the product } \\
\text { or service whose needs or } \\
\text { requirements must } \\
\text { accommodated }\end{array}$ & None & $\begin{array}{l}\text { Oloruntoba and Gray, 2009; } \\
\text { Kovács and Spens, } 2007 ; \\
\text { Altay and Green, } 2006\end{array}$ \\
\hline $\begin{array}{l}\text { Implementing } \\
\text { partner (IP) }\end{array}$ & $\begin{array}{l}\text { These are specific organizations, } \\
\text { with specific functions (such as } \\
\text { water, shelter etc) operating } \\
\text { between the international } \\
\text { humanitarian organisations } \\
\text { (IHOs) and the aid } \\
\text { beneficiaries/end-users of the } \\
\text { relief effort. }\end{array}$ & $\begin{array}{l}\text { Yes between } \\
\text { IP and IHO. }\end{array}$ & $\begin{array}{l}\text { Matopoulos et al., 2014; } \\
\text { Kovács and Spens, 2011; } \\
\text { Thomas and Mizushima, } 2005\end{array}$ \\
\hline $\begin{array}{l}\text { Donor } \\
\text { (governmental, } \\
\text { institutional, } \\
\text { private) }\end{array}$ & $\begin{array}{l}\text { Provides funding for } \\
\text { IHOs to procure staff, relief } \\
\text { goods, and transport them to } \\
\text { disaster sites for relief } \\
\text { distribution. } \\
\text { The donor not only provides } \\
\text { funding but may also provide } \\
\text { supplies such as clothing, food } \\
\text { or cooking oil, here the donor } \\
\text { acts like a supplier, except that } \\
\text { the donor does not get paid. }\end{array}$ & $\begin{array}{l}\text { Yes between } \\
\text { donor and } \\
\text { IHO. } \\
\text { None when } \\
\text { donor acts as a } \\
\text { supplier (in- } \\
\text { kind } \\
\text { donations). }\end{array}$ & $\begin{array}{l}\text { Heaslip, 2013; } \\
\text { Holguín-Veras et al., 2013; } \\
\text { Oloruntoba and Gray, 2009; } \\
\text { Van Wassenhove, 2006 } \\
\text { Kovács and Spens, 2009; } \\
\text { Van Wassenhove, 2006 }\end{array}$ \\
\hline $\mathrm{IHO}$ & $\begin{array}{l}\text { Can act as donor, implementing } \\
\text { partner, or delivery partner in } \\
\text { particular programmes or } \\
\text { through Clusters. }\end{array}$ & $\begin{array}{l}\text { Yes between } \\
\text { IHOs. }\end{array}$ & $\begin{array}{l}\text { Kovács, 2014; } \\
\text { Jahre and Jensen, } 2010\end{array}$ \\
\hline UN Agency & $\begin{array}{l}\text { Specific organization, with } \\
\text { specific functions (such as } \\
\text { water, shelter etc). Can act as } \\
\text { delivery partners in particular } \\
\text { programmes or through } \\
\text { Clusters. }\end{array}$ & $\begin{array}{l}\text { Yes between } \\
\text { donor, IHO } \\
\text { and IP. }\end{array}$ & $\begin{array}{l}\text { Heaslip, 2013; } \\
\text { Kovács and Spens, 2011; } \\
\text { Jahre and Jensen, } 2010\end{array}$ \\
\hline $\begin{array}{l}\text { Logistics Service } \\
\text { Provider }\end{array}$ & $\begin{array}{l}\text { Specific organization, with } \\
\text { specific logistics capabilities, } \\
\text { (such as distribution, cold chain, } \\
\text { warehousing, etc). Can act as } \\
\text { delivery partners in particular } \\
\text { programmes. }\end{array}$ & $\begin{array}{l}\text { Yes between } \\
\text { donor, IHO, } \\
\text { UN Agency } \\
\text { and IP. }\end{array}$ & $\begin{array}{l}\text { Abidi et al., 2015; } \\
\text { Bealt et al., 2016; } \\
\text { Heaslip, 2013; } \\
\text { Vega and Roussat, } 2015\end{array}$ \\
\hline
\end{tabular}

Table 3: IHOs customers 


\begin{tabular}{|c|c|c|c|c|c|}
\hline Organisation & $\begin{array}{l}\text { Type of relief } \\
\text { involvement }\end{array}$ & $\begin{array}{l}\text { UNWFP } \\
\text { "Goods" }\end{array}$ & $\begin{array}{l}\text { UNWFP } \\
\text { "Services" }\end{array}$ & $\begin{array}{l}\text { UNWFP } \\
\text { Customers }\end{array}$ & $\begin{array}{l}\text { Expenditure } \\
\text { US \$ }\end{array}$ \\
\hline $\begin{array}{l}\text { United Nations } \\
\text { World Food } \\
\text { Programme } \\
\text { (UNWFP) }\end{array}$ & $\begin{array}{l}\text { Over } 75 \\
\text { countries, } \\
\text { Emergencies, } \\
\text { livelihoods, } \\
\text { food, education }\end{array}$ & Food & $\begin{array}{l}\text { Information } \\
\text { consultancy; } \\
\text { Procurement; } \\
\text { Customs } \\
\text { clearance; } \\
\text { Warehousing; } \\
\text { Distribution; } \\
\text { Inventory } \\
\text { Management; } \\
\text { Fleet service; } \\
\text { Postponement; } \\
\text { Training }\end{array}$ & $\begin{array}{l}\text { Governments } \\
\text { Donors } \\
\text { IHOs } \\
\text { UN Agencies } \\
\text { NGOs } \\
\text { Implementing } \\
\text { Partners } \\
\text { Beneficiaries }\end{array}$ & 2.97 billion \\
\hline
\end{tabular}

Table 4: UNWFP move from product to service

\begin{tabular}{|c|c|c|}
\hline \multirow{4}{*}{ 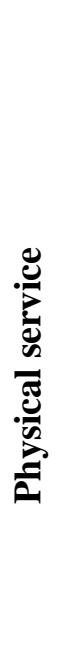 } & $\begin{array}{c}\text { Asset based - service } \\
\text { extension }\end{array}$ & Service revolution \\
\hline & $\begin{array}{l}\text { Warehousing } \\
\text { Inventory management } \\
\text { Postponement } \\
\text { Transportation } \\
\text { Distribution }\end{array}$ & $\begin{array}{l}\text { Information consultancy } \\
\text { 4PL } \\
\text { Training } \\
\text { Cash }\end{array}$ \\
\hline & $\begin{array}{l}\text { Traditional: thematic } \\
\text { focus }\end{array}$ & $\begin{array}{l}\text { Network based - } \\
\text { networked service }\end{array}$ \\
\hline & $\begin{array}{l}\text { Food } \\
\text { Water } \\
\text { Sanitation } \\
\text { Shelter } \\
\text { Health care } \\
\text { Education }\end{array}$ & $\begin{array}{l}\text { Track and trace } \\
\text { Procurement } \\
\text { Custom clearance } \\
\text { Service standardisation } \\
\text { Consolidation }\end{array}$ \\
\hline
\end{tabular}

Table 5: Types of International Humanitarian Organisation 


\begin{tabular}{|c|c|c|c|}
\hline Trend & Impact of trend & Service impact on IHOs & Service opportunities \\
\hline Cash for transfer & $\begin{array}{l}\text { - Beneficiaries now have } \\
\text { purchasing power } \\
\text { - Increasing array of } \\
\text { financial platforms }\end{array}$ & $\begin{array}{l}\text { - } \begin{array}{l}\text { New market with } \\
\text { stronger } \\
\text { proposition }\end{array} \\
\text { - } \begin{array}{l}\text { Technoluegical } \\
\text { development provides }\end{array} \\
\text { new consumer segment }\end{array}$ & $\begin{array}{l}\text { - Platforms needed to be } \\
\text { developed } \\
\text { - Growth opportunities } \\
\text { - Changing needs of donors }\end{array}$ \\
\hline Funding & $\begin{array}{l}\text { - Pooled funding } \\
\text { centralise } \\
\text { response fund (CERF) }\end{array}$ & $\begin{array}{l}\text { New service offering } \\
\text { enabled by partnering to } \\
\text { co-produce value }\end{array}$ & $\begin{array}{l}\text { - Social media } \\
\text { - Crowdfunding }\end{array}$ \\
\hline Cluster & $\begin{array}{l}\text { - Improved coordination } \\
\text { - Information sharing } \\
\text { - Involvement of local } \\
\text { community }\end{array}$ & 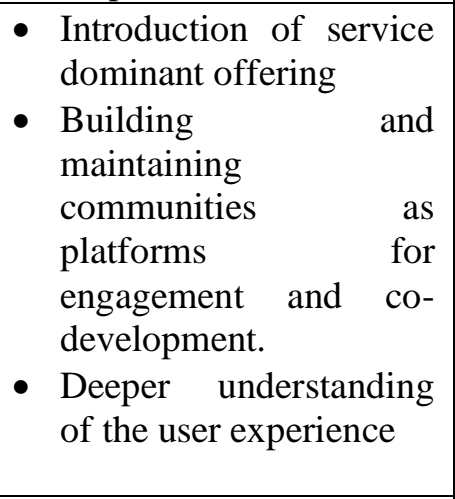 & $\begin{array}{l}\text { - New service offerings } \\
\text { enabled by partnering to } \\
\text { co-produce value } \\
\text { - Building (strategic) } \\
\text { alliances with } \\
\text { "competitors" to develop } \\
\text { business opportunities. } \\
\text { - Building dynamic } \\
\text { capabilities by integrating } \\
\text { and reconfiguring } \\
\text { resources }\end{array}$ \\
\hline $\begin{array}{l}\text { Mobile } \\
\text { technologies }\end{array}$ & 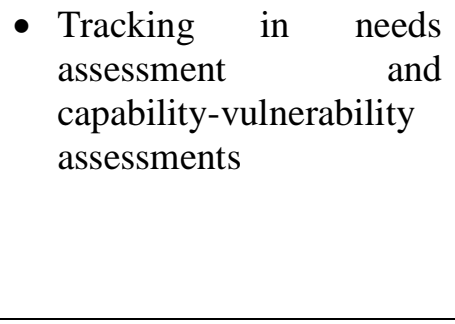 & $\begin{array}{l}\text { - Move towards CTPs } \\
\text { - Supply chain visibility } \\
\text { - Infrastructure } \\
\text { assessment } \\
\text { mapping en route } \\
\text { - Deeper understanding } \\
\text { of beneficiary needs }\end{array}$ & $\begin{array}{l}\text { - Mobile banking } \\
\text { - Tracking and tracing }\end{array}$ \\
\hline $\begin{array}{l}\text { Emergency staff } \\
\text { surge capacity }\end{array}$ & $\begin{array}{l}\text { - Flexibility of HL } \\
\text { - Integrated IHO-supplier } \\
\text { teams } \\
\text { - Extended understanding } \\
\text { of HL outside of the } \\
\text { sector } \\
\text { - High job rotation and } \\
\text { staff fluctuation }\end{array}$ & $\begin{array}{l}\text { - Training non-IHO staff } \\
\text { on HL activities }\end{array}$ & $\begin{array}{l}\text { - HL training required for } \\
\text { surge staff } \\
\text { - Databases / rosters of } \\
\text { qualified personnel } \\
\text { - Volunteer management }\end{array}$ \\
\hline $\begin{array}{l}\text { Stockpiling of } \\
\text { goods in strategic } \\
\text { locations }\end{array}$ & $\begin{array}{l}\text { - } \text { Higher level of } \\
\text { preparedness } \\
\text { - Speed of response } \\
\text { - Standardisation of items }\end{array}$ & $\begin{array}{l}\text { - Inventory pre- } \\
\text { positioning } \\
\text { - Warehousing services } \\
\text { - Packing, and kitting in } \\
\text { warehouses } \\
\text { - Development of inter- } \\
\text { agency kits }\end{array}$ & $\begin{array}{l}\text { - Warehousing services } \\
\text { - Packing, labelling, kitting } \\
\text { services } \\
\text { - Postponement strategies } \\
\text { - Development of Enterprise } \\
\text { Resource Planning (ERP) } \\
\text { systems for HL }\end{array}$ \\
\hline
\end{tabular}

Table 6: Humanitarian Logistics: New Trends and their impacts on an increasing service orientation 


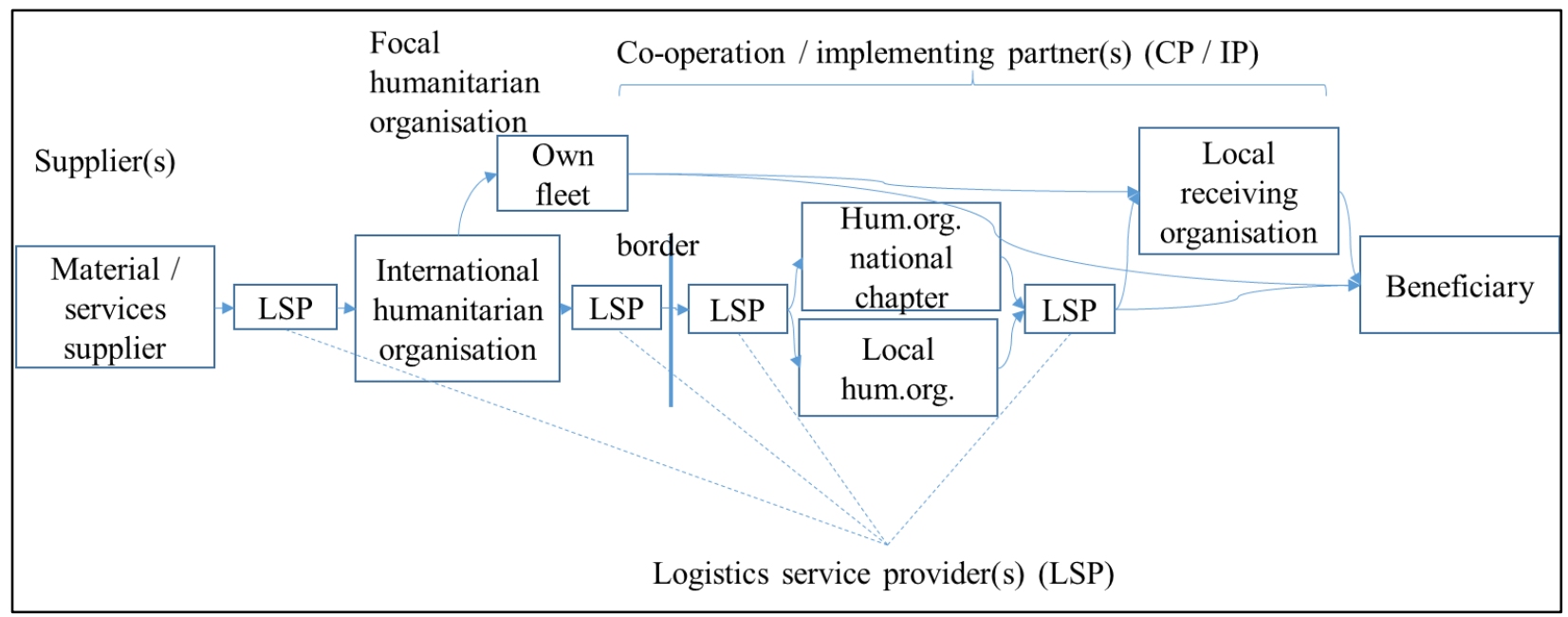

Figure 1: Service tiering of a cross-border delivery 